\section{Science planners ask for more}

\section{Washington}

AN urgent plea for more federal support for undergraduate science and engineering education has been made by a special task committee of the National Science Board, the policy-making arm of the National Science Foundation (NSF). The board has endorsed the report*, which states that NSF support for undergraduate education should be increased by $\$ 100$ million by 1989 from its current level of about $\$ 11$ million, and has asked NDF director Erich Bloch to prepare a plan of action.

The new report provides much-needed ammunition for Bassam Shakhashiri, head of NSF's off-and-on science and engineering education directorate. The directorate, which was abolished in 1981, has faced an uphill struggle since its reestablishment in 1983, competing for funds with NSF's research directorates. Its current level of support, $\$ 87$ million, is still way below the peak in the late 1960s; almost all its growth since the nadir in 1981 has been for pre-college education.

The task committee, chaired by Homer Neal of the State University of New York, concludes that, unless immediate action is taken, the United States "will not meet its current requirements for science and engineering personnel, much less respond to future challenges". It identifies three problems that require "attention of the highest priority". They are: laboratory instruction (which is "too frequently carried out in facilities that are obsolete and inadequate"); faculty members (where there are in some fields "serious shortages"); and courses and curricula ("frequently out of date, unimaginative and poorly organized"). Faculty shortages in engineering disciplines occasion "extraordinary levels of concern": 8.5 per cent of budgeted positions are vacant.

Obedient to the current administration's belief that state and local governments should bear primary responsibility for pre-graduate education, the task force is careful to emphasize the obligations of governments other than the federal. Going beyond its mandate to consider NSF's role, the committee also urges that states, academic institutions, private industry and other federal agencies should improve their efforts. But it also says that NSF should take "bold steps to establish itself in a position of leadership" in undergraduate education in mathematics, engineering and the sciences. It proposes a $\$ 50$ million budget increase in 1988 , rising to the target of an extra $\$ 100$ million the following year.

One of the committee's chief concerns is the projected decline in the size of the $18-19$ age group. The first effects may

already be apparent; between 1973 and 1983, the number of undergraduate science majors fell by 15 per cent. In addition, science courses are becoming less popular. Faculty members are ageing and have little incentive to keep up to date in teaching. In some institutions, laboratory in-struction is being abandoned in intro-ductory courses.

The task committee's report can be expected to receive a friendly reception on Capitol Hill, which has traditionally been sympathetic to education. The welcome

\section{Soviet rivers}

SOVIET plans for diverting major rivers have caused a row within the Soviet Academy of Sciences. Academician Dmitrii Likhachev, interviewed on Soviet television, has accused the Soviet presidium of bias and the "violation of ethical norms" in holding a conference on the proposed diversion of the waters of the north-flowing rivers of Siberia without inviting representatives of the humanities who, in Likhachev's opinion, should have been there to "defend the interests of culture". Likhachev is a member of the departments of history and of literature and language of the Academy of Sciences.

By the time of Likhachev's broadcast, the issue of the river diversion had already become somewhat theoretical. After considerable opposition (see Nature 319, $88 ; 1986$ ), a paragraph relating to the river diversion project was omitted from the version of the guidelines for the next fiveyear plan (1986-90), adopted by the 27th Party Congress last month.

In fact, many of the participants at the conference were also opposed to the scheme, holding that the diversion is now unnecessary because, contrary to the forecasts of the All-Union State Institute for Water Resources, the level of the Caspian Sea has ceased to decline. Speakers are also said to have quoted an opinion of the World Meteorological Organization that the current increased precipitation in the Volga basin will be maintained for 50 years.

Others agreed that the river diversion plans were based on forecasts of water usage that took no account of how recycling methods in industry, and the more rational use of water in agriculture, will gradually reduce water consumption. Writing in Pravda in mid-February, a group of five eminent economists, agronomists and geologists noted that by reducing waste and "justifiably cutting irrigation norms" in the arid south, no less than $60 \mathrm{~km}^{3}$ of water could be saved each year, while the introduction of water-

\title{
Conflict of interest in academy
}

will be enhanced by the committee's emphasis on schemes that require local governments to provide matching support for federal dollars; a subcommittee of the House of Representatives has already moved to increase funding above the administration's proposed sum for 1987 , although there remain many obstacles. But, as for all federal expenditures, the Gramm-Rudman deficit reduction act makes predicting congressional action difficult. Whether the pleas will fall on receptive ears in the White House is less certain.

Tim Beardsley

*Report of the NSB Task Committee on Undergraduate Science and Engineering Education to the National Science Board, 1986. conserving farming techniques would make it possible to use up to $70 \mathrm{~km}^{3}$ of local water annually for crop-raising in the southern steppes. These estimates are "many times higher" than the proposed volume of water (about $6 \mathrm{~km}^{3}$ annually) to be redistributed by the diversion scheme.

Likhachev's complaint is not based on the unexpected natural recovery of the level of the Caspian, although he mentioned that the rise in the water level has already flooded a number of health resorts built too close to the shore of the supposedly shrinking sea. He concentrated instead on what he saw as the ethical issues. Not only were the representatives of the humanities excluded from the conference, but the title of the conference was unethical in referring to the "first stage" of the diversion project. Likhachev said that the "first stage" should not be discussed without knowing how many more stages there would be, especially when the first stage was to go ahead "without a vote".

Likhachev clearly has little faith in official assurances that no relics of mediaeval architecture will be inundated by the diversion. He demanded to know why the population of the Russian north, "which has lived there since the twelfth century", should have to lose its monuments to provide water for the south. $\mathrm{He}$ was also concerned that the third stage of the diversion plan would affect the Pechora, whereupon, he said, the fate of the Komi people, "one of the most interesting and cultured people of the Russian north", would "be sealed".

Conflicts between the humanities and the exact sciences do not often manifest themselves in the Soviet Union. Likhachev's attack on the ethics of the academy presidium, although consistent with the policy of open criticism encouraged by the new regime, could well call into question the role of the humanities in an academy that is increasingly focused on science in its narrower sense.

Vera Rich 